УДК 338.001.36: 656.078.89

JEL L10, M21, R41

DOI 10.31375/2226- 1915-2019-4-92-103

Н.Г. Гребенник к.е.н., доцент, доцент кафедри «Підприємництво та туризм» nataly.grebennyk@gmail.com https://orcid.org/0000-0002-1554-0697

В.В. Старіков студент магістратури спеціальност «Підприємництво, торгівля та біржова діяльність» starikovvlad95@gmail.com

Одеський національний морський університет, Одеса, Украӥна

\section{МЕТОДИЧНІ ПІДХОДИ ДО ОЦІНКИ \\ КОНКУРЕНТОСПРОМОЖНОСТІ ЕКОНОМІЧНОГО ПОТЕНЦААЛУ ПОРТОВОГО ОПЕРАТОРА}

Анотація. $У$ статті досліджено сутність економічного потенціалу, його складові та підходи до очінки його конкурентоспроможності.

Динамічність галузі портової діяльності $i$ високий рівень конкуренції в ичьому секторі змушують портових операторів забезпечувати здат ність до трансформації своїх ресурсів під впливом змін на ринку. Раиіональне використання всіх елементів економічного потенціалу портового опе ратора означає можливість для його довгострокового ефективного функиіонування в секторі портових послуг. Це викликає необхідність оцінки економічного потениіалу за допомогою послідовної очінки його предметних складових, таких як виробнича, трудова, фінансова та ринкова

У статті запропоновані методичні підходи до оцінки проекту розвитку портового оператора з метою підвищення конкурентоспроможності його економічного потенціалу. Були виконані розрахунки на базі інформачії про операторів контейнерних терміналів в портах України, яка $є$ у відкритому доступі. В розрахунках не приймалися до уваги проекти розвитку, які заплановані до реалізаиії, або вже реалізовуються.

Отримані результати розрахунків свідчать про те, шо наведені методичні підходи можуть бути використані на практиці і бути більш точними за умови використання більш повної інформації. Інтегральний показник конкурентоспроможності економічного потенціалу може бути визначений для різних інвестиційних проектів для вибору найкрашього з них.

Ключові слова: економічний потенціал, конкурентоспроможність, конкурентоспроможність економічного потенціалу, портовий оператор.

() Гребенник Н.Г., Старіков В.В., 2019
УДК 338.001.36: 656.078.89

JEL L10, M21, R41

DOI 10.31375/2226- 1915-2019-4-92-103

Н.Г. Гребенник к.э.н., доцент, доцент кафедры Предпринимательство и туризм» nataly.grebennyk@gmail.com https://orcid.org/0000-0002-1554-0697

B.В. Стариков студент магистратуры специальности «Предпринимательство, торговля и биржевая деятельность» starikovvlad95@gmail.com

Одесский национальный морской университет, Одесса, Украина

\section{МЕТОДИЧЕСКИЕ ПОДХОДЫ К ОЦЕНКЕ КОНКУРЕНТОСПОСОБНОСТИ ЭКОНОМИЧЕСКОГО ПОТЕНЦИАЛА ПОРТОВОГО ОПЕРАТОРА}

Аннотация. $B$ cmambe исследована сущность экономического потенииала, его составляющие и подходы к оценке его конкурентоспособности.

Динамичное развитие портовой деятельности и высокий уровень конкуренции в этом секторе заставляют портовых операторов обеспечивать способность к трансформации своих ресурсов под влиянием изменений на рынке. Рачиональное использование всех элементов экономического потенциала портового оператора означает возможность его долгосрочного эффективного функиионирований в секторе портовых услуг. Это вызывает необходимость оиенки экономического потенииала с помошью последовательной оченки его предметных составляющих, таких как производственная, трудовая, финансовая и рыночная.

В статье предложены методические подходы к оченке проекта развития портового оператора с иелью повышения конкурентоспособности его экономического потенциала. Они содержат следуюшие блоки: анализ внешних факторов, анализ конкурентной среды, анализ внутренних факторов, выбор варианта развития, выбор объекта инвестирования, выбор проекта из ряда альтернативных вариантов.

Полученные результаты расчетов свидетельствуют о том, что приведенные методические подходы могут быть использованы на практике и быть более точными при использовании более полной информации. Интегральный показатель конкурентоспособности экономического потенииала может быть определен для различных инвестиционных проектов для выбора лучшего из Hux.

Ключевые слова: экономический потенциал, конкурентоспособность, конкурентоспособность экономического потенциала, портовый onepamop. 
UDC 338.001.36: 656.078.89

JEL L10, M21, R41

DOI 10.31375/2226-1915-2019-4-92-103

N. Grebennyk

$\mathrm{PhD}$, Docent of Department «Entrepreneurship and tourism» nataly.grebennyk@gmail.com

https://orcid.org/0000-0002-1554-0697

V. Starikov

graduate student «Entrepreneurship, trade and exchange activity» starikovvlad95@gmail.com

Odessa National Maritime University

\title{
METHODICAL APPROACHES \\ TO EVALUATING THE COMPETITIVENESS \\ OF THE PORT OPERATOR'S ECONOMIC POTENTIAL
}

\begin{abstract}
The article explores the essence of economic potential, its components and approaches to assessing its competitiveness.

The market for port activities is developing dynamically. There is a high level of competition in this sector. This forces port operators to provide the ability to transform their resources under the influence of changes in the market. The rational use of all elements of the economic potential of the port operator means the possibility of its long-term effective functioning in the port services sector. This necessitates the assessment of economic potential using a consistent assessment of its subject components, such as production, labor, financial and market. Competitiveness of potential can be assessed by comparing the competitive positions of several enterprises in a particular market. It is imperative to comply with the compatibility of evaluation parameters: technology, potential equipment capabilities, staff level, management system, level of innovation, state of communications, level of marketing policy and the like.

The article proposes methodological approaches to assessing the development project of a port operator in order to increase the competitiveness of its economic potential. They contain the following blocks: analysis of external factors, analysis of the competitive environment, analysis of internal factors, choice of development option, choice of investment object, project selection from a number of alternative options. Calculations were made based on information on container terminal operators in Ukrainian ports, which is publicly available. The calculations did not take into account development projects that are planned for implementation or are already being implemented.
\end{abstract}

The article analyzes the rating of the largest container terminals in the world, the rating of the EU container ports, the indicators of container processing in the ports of the Black Sea and the Azov basin and container through seaports of Ukraine.

The obtained calculation results indicate that the above methodological approaches can be used in practice and be more accurate when using more complete information. An integral indicator of the competitiveness of economic potential can be determined for various investment projects to choose the best one.

Keywords: economic potential, competitiveness, competitiveness of economic potential, port operator 
DEVELOPMENT OF MANAGEMENT

AND ENTREPRENEURSHIP METHODS ON TRANSPORT, № 4 (69), 2019
РОЗВИТОК МЕТОДІВ

УПРАВЛІННЯ ТА ГОСПОДАРЮВАННЯ

НА ТРАНСПОРТІ, № 4 (69), 2019
Постановка проблеми. Динамічний розвиток економіки вимагає впровадження в господарську практику сучасного економічного інструментарію для аналізу і оцінки роботи підприємства, який дозволить врахувати не лише наявні ресурси, а також допоможе врахувати його перспективні можливості. До складу популярних розробок в цій області слід віднести визначення економічного потенціалу підприємства та оцінку його конкурентоспроможності.

Останні кілька років обсяги вантажоперевезень світовим флотом зростають. Цей факт пов'язують у першу чергу 3 тим, що економічна напруженість, яка викликана світовою фінансовою кризою, стала спадати. Наслідком чого стало зростання товарообігу між країнами, що знайшло відображення в збільшення обсягів перевезення та перевантаження вантажів за участю морського транспорту.

При цьому, виробничі потужності портів в Україні не завантажені в повному обсязі. Велика кількість стивідорних компаній на ринку портових послуг обумовлює значний рівень конкуренції в цьому сегменті ринку. Це викликає необхідність оцінки конкурентоспроможності потенціалу портових операторів на ринку портових послуг та розробки заходів для його підвищення.

Огляд останніх досліджень та публікацій. Поняття економічний потенціал $є$ відносно новим в економічній теорії, але навіть йому присвячено багато наукових праць, які іноді $€$ дискусійними.

Зокрема, в економічній літературі широко використовуються разом терміни «економічний потенціал» $\mathrm{i}$ «ресурсний потенціал». Проте, помилковим $є$ ототожнення цих двох понять. При дослідженні ресурсного потенціалу розглядають лише наявні ресурси, що $є$ у підприємства. Зокрема, в роботі [6] характеризується ресурсний потенціал, як сукупність наявних у розпорядженні підприємства ресурсів (земельні, трудові, матеріальні). Комаров М.А. і його співавтори визначають ресурсний потенціал як систему ресурсів, взаємозалежну сукупність матеріально-речовинних, енергетичних, інформаційних засобів, а також самих працівників, які використовують (або можуть використовувати) їх у процесі виробництва матеріальних благ і послуг [8]. Більшість акторів пропонує відокремлювати поняття економічного потенціалу та розглядати ресурсний потенціал, як його складову.

Результати дослідження теорії конкуренції наведені в роботах вчених-класиків Д. Рікардо, М. Портера. К.Р. Макконнелла, С.Л. Брю. Поняття конкуренції та питання змісту конкуренції в економіці досліджуються у роботах Р.А. Фатхутдінова, Д.Ю. Юданова та ін. Механізм забезпечення конкурентоспроможності потенціалу підприємства висвітлений у працях К.С.Борзенкової [2], Н.С. Краснокутської [4], Є.В. Попова та ін.

$\mathcal{E}$ наукові праці, які присвячені дослідженню конкуренції в портовій діяльності $[5 ; 11]$ та описують напрямки підвищення конкурентоспроможності операторів контейнерних терміналів у морських портах $[1 ; 12]$.

Специфіка роботи портового оператора вимагає поглибленого вивчення поняття та способів оцінки конкурентоспроможності економічного потенціалу підприємства в порту. 
РОЗВИТОК МЕТОДІВ

УПРАВЛІННЯ ТА ГОСПОДАРЮВАННЯ

НА ТРАНСПОРТІ, № 4 (69), 2019
Метою роботи $\epsilon$ визначення змісту конкурентоспроможності економічного потенціалу портового оператора та дослідження методичних підходів до його оцінки.

Основний матеріал дослідження. Під економічним потенціалом підприємства зазвичай пропонується розуміти його здатність забезпечувати своє довгострокове функціонування і досягнення стратегічних цілей на основі використання системи наявних ресурсів [ $4 ; 8]$.

У свою чергу, конкурентоспроможність економічного потенціалу підприємства - це його комплексна порівняльна характеристика, яка відображає ступінь переваг над підприємствами-конкурентами за сукупністю оціночних показників діяльності на певних ринках, за певний проміжок часу $[2 ; 6]$.

Відповідно до закону України «Про морські порти України» «портовий оператор - суб'єкт господарювання, що здійснює експлуатацію морського терміналу, проводить вантажно-розвантажувальні роботи, обслуговування та зберігання вантажів, обслуговування суден і пасажирів, а також інші пов'язані 3 цим види господарської діяльності» [7, ст. 1].

Для розробки пропозицій щодо зростання конкурентоспроможності потенціалу портового оператора необхідно виявити можливості і здатності всіх елементів його потенціалу, тобто оцінити їх корисні властивості, які можна оптимально використовувати для досягнення певних цілей в процесі надання портових послуг.

Портовий оператор в процесі своєї діяльності взаємодіє з багатьма суб'єктами господарювання. В сфері портової діяльності функціонують судноплавні компанії, стивідорні компанії, підприємства сервісної діяльності (експедиторські, агентські, сюрвейєрські тощо) та багато інших організацій, які здійснюють та організують процес транспортування вантажів.

Динамічність галузі портової діяльності і високий рівень конкуренції на ринку портових послуг змушують портових операторів мати здатність до трансформації своїх внутрішніх складових під впливом змін, що відбуваються на ринку портових послуг. Раціональне використання всіх елементів економічного потенціалу означає можливість для його довгострокового ефективно функціонувати в секторі портових послуг. Це викликає необхідність оцінки економічного потенціалу за допомогою послідовної оцінки його предметних складових. До предметних складових економічного потенціалу відносять:

1) виробничий потенціал: спеціалізація портового оператора, пропускна спроможність, потужності перевантажувального устаткування, складські площі, пропускна спроможність під'їзних колій, можливості використання сировини і матеріалів, можливості професійних кадрів;

2) фінансовий потенціал: потенційні фінансові показники (прибутковості, ліквідності, платоспроможності), потенційні інвестиційні можливості, інвестиційна привабливість;

3) трудовий потенціал: сукупність здатностей і можливостей трудових ресурсів забезпечувати ефективну організацію та здійснення перевантаження вантажів;

4) ринковий потенціал: потенційний попит на портові послуги, 
РОЗВИТОК МЕТОДІВ

УПРАВЛІННЯ ТА ГОСПОДАРЮВАННЯ

НА ТРАНСПОРТІ, № 4 (69), 2019 надання послуг з берегового сервісного обслуговування, що знаходить відображення у показнику - частка ринку портового оператора; взаємодія портового оператора 3 ринком праці і ринком факторів виробництва (паливо, матеріали тощо). Конкурентоспроможність потенціалу можна оцінювати шляхом порівняння конкурентних позицій кількох підприємств на певному ринку. При цьому обов'язковою вимогою $є$ порівняність оціночних параметрів: технології, потенційні можливості обладнання, рівень персоналу, система управління, piвень інновацій, стан комунікацій, рівень маркетингової політики тощо.

Забезпечення конкурентоспроможності здійснюється на різних рівнях: оперативному, тактичному або стратегічному. Залежно від специфіки підприємства критерії та показники конкурентоспроможності можуть змінюватися. Суть оцінки полягає в розрахунку комплексного показника конкурентоспроможності 3 урахуванням диференціації важливості окремих критеріїв і показників, що характеризують різні сторони діяльності господарюючого суб'єкта.

Проведене дослідження дозволило визначити методичні підходи до оцінки проекту розвитку портового оператора з метою підвищення конкурентоспроможності його економічного потенціалу (рис. 1).

Була виконана апробація запропонованих методичних підходів для операторів контейнерних терміналів у морських портах України.

Аналіз зовнішніх факторів показав вигідне географічне положення українських портів, нестабільну політичну та економічну ситуацію в країні, проблемні митну та податкову по- літики, позитивні тенденції розвитку світової торгівлі, високий рівень інтеграції у світову транспортну мережу, низький рівень розвитку транспортної інфраструктури країни, задовільний рівень розвитку логістичної інфраструктури, неконкурентний рівень портових зборів і зодовільний рівень розвитку інформаційних технологій $[11 ; 13]$.

Аналіз роботи контейнерних терміналів в світі показав, що в 2018 році на регіональному рівні порти Азії продовжували домінувати в контейнеропотоках. Їх частка склала майже $78 \%$ із загального контейнеропотоку у світі - 498,76 мільярдів TEU, що оброблялися в 50-ти найбільших контейнерних портах світу (таблиця 1).

Спостерігається зростання контейнеропотоків через контейнерні порти Європи. У 2018 році 15 великих портів ЄС продемонстрували зростання на 4,8 \% - майже такий же, який був зареєстрований у 2017 році $(4,6 \%)$. У 2015 році в ТОП-15 контейнерних портів Свропи спостерігали не менші показники зниження на $1,6 \%$ у порівнянні з 2014 роком. У 2016 році був зафіксований середній зріст на 2,1\%.

В Україні зростання виявилося найбільш значним - на $17 \%$. Україна повернула собі лідерство серед чорноморських країн, яке було втрачено в 2017 році.

Морські порти України у 2018 році збільшили контейнерооброт в порівнянні з 2017 роком на 43,4 \% до 846485 TEU. Про це свідчать фактичні дані ДП «Адміністрація морських портів України» (АМПУ) (таблиця 4). 
DEVELOPMENT OF MANAGEMENT AND ENTREPRENEURSHIP METHODS ON TRANSPORT, № 4 (69), 2019
РОЗВИТОК МЕТОДІВ

УПРАВЛІННЯ ТА ГОСПОДАРЮВАННЯ

НА ТРАНСПОРТІ, № 4 (69), 2019
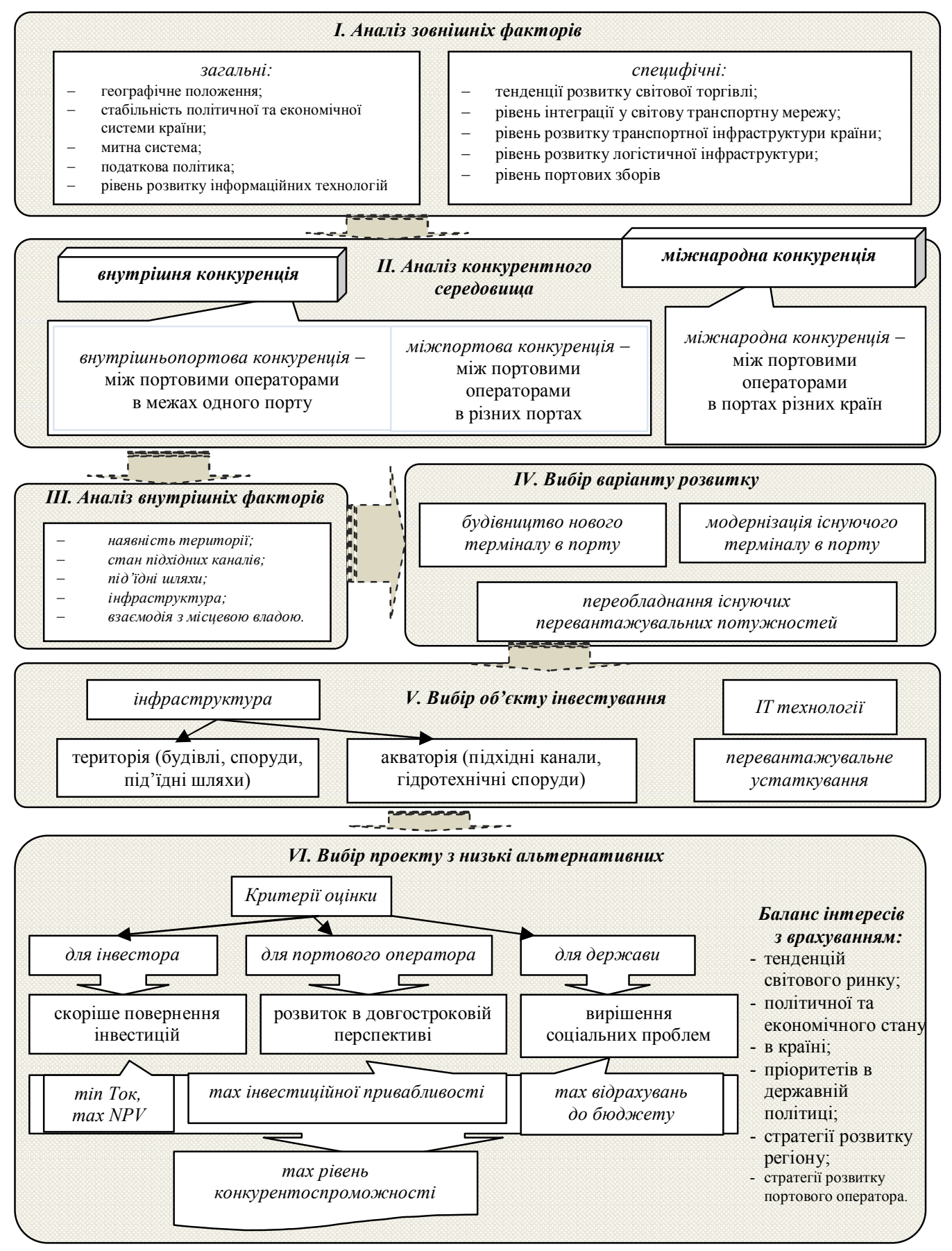

Рис. 1. Методичні підходи до оиінки проекту з метою підвищення конкурентоспроможності економічного потенціалу портового оператора

Джерело: розроблено авторами з використанням [1; 2; 4; 5;8] 
DEVELOPMENT OF MANAGEMENT AND ENTREPRENEURSHIP METHODS ON TRANSPORT, № 4 (69), 2019
РОЗВИТОК МЕТОДІВ

УПРАВЛІННЯ ТА ГОСПОДАРЮВАННЯ

НА ТРАНСПОРТІ, № 4 (69), 2019

Рейтинг найбільших контейнерних терміналів світу

\begin{tabular}{|c|l|l|c|c|c|}
\hline \multirow{2}{*}{ Рейтинг } & \multirow{2}{*}{ Порт } & \multirow{2}{*}{ Країна } & \multicolumn{2}{c|}{\begin{tabular}{c} 
Контейнерооборот, \\
\multirow{2}{*}{ Прлн. ТЕU }
\end{tabular}} \\
\cline { 4 - 5 } & & & 2018 рік & 2017 рік & \\
\hline 1 & Шанхай & Китай & 42,01 & 40,23 & 4,4 \\
\hline 2 & Сингапур & Сінгапур & 36,60 & 33,67 & 8,7 \\
\hline 3 & Нінбо-Жушань & Китай & 26,35 & 24,61 & 7,1 \\
\hline 4 & Шеньчжень & Китай & 25,73 & 25,21 & 2,1 \\
\hline 5 & Гуанчжоу & Китай & 21,92 & 20,37 & 7,6 \\
\hline 6 & Пусан & Південна Корея & 21,66 & 20,47 & 5,8 \\
\hline 7 & Гонконг & Китай & 19,60 & 20,76 & $-5,6$ \\
\hline 8 & Циндао & Китай & 19,31 & 18,30 & 5,5 \\
\hline 9 & Тяньцзінь & Китай & 16,00 & 15,07 & 6,2 \\
\hline 10 & Джебель Алі & ОАЕ & 14,95 & 15,37 & $-2,7$ \\
\hline 11 & Роттердам & Нідерланди & 14,50 & 13,73 & 5,6 \\
\hline 12 & Порт Кланг & Малайзія & 12,32 & 11,98 & 2,8 \\
\hline 13 & Антверпен & Бельгія & 11,10 & 10,45 & 6,2 \\
\hline 14 & Сямень & Китай & 10,70 & 10,38 & 3,1 \\
\hline 15 & Гаосюн & Тайвань & 10,45 & 10,27 & 1,7 \\
\hline 16 & Далянь & Китай & 9,77 & 9,70 & 0,7 \\
\hline 17 & Лос-Анджелес & США & 9,46 & 9,34 & 1,3 \\
\hline 18 & Танджунг Пелепас & Малайзія & 8,96 & 8,38 & 6,9 \\
\hline 19 & Гамбург & Німеччина & 8,77 & 8,86 & $-1,0$ \\
\hline 20 & Порти Кейхін & Японія & 8,14 & 7,98 & 2,0 \\
\hline & & & & & \\
\hline
\end{tabular}

Джерело: [14]

Таблиия 2

Рейтинг контейнерних портів СС

\begin{tabular}{|c|c|l|c|c|}
\hline \multicolumn{2}{|c|}{ Рейтинг } & \multicolumn{1}{|c|}{ Порт } & $\begin{array}{c}\text { Контейнерооборот } \\
\text { в 2018 г., тис. ТЕU }\end{array}$ & Приріст, \% \\
\hline 2018 рік & 2017 рік & & 14513 & $+5,7$ \\
\hline 1 & 1 & Роттердам & 11100 & $+6,2$ \\
\hline 2 & 2 & Антверпен & 8730 & $-1,0$ \\
\hline 3 & 3 & Гамбург & 5467 & $-1,3$ \\
\hline 4 & 4 & Бремерхафен & 5104 & $+5,6$ \\
\hline 5 & 5 & Валенсія & 4908 & $+20,9$ \\
\hline 6 & 8 & Пирей & 4772 & $+8,9$ \\
\hline 7 & 6 & Альхесирас & 4161 & - \\
\hline 8 & 7 & Фелікстоу & 3423 & $+15,3$ \\
\hline 9 & 10 & Барселона & 3310 & $+5,1$ \\
\hline 10 & 9 & Марсашлок & 2884 & 0,0 \\
\hline 11 & 11 & Гавр & 2609 & $-0,5$ \\
\hline 12 & 12 & Генуя & 2301 & $-6,0$ \\
\hline 13 & 13 & Джойя-Тауро & 1995 & - \\
\hline 14 & 14 & Саутгммптон & 1949 & $+23,3$ \\
\hline 15 & - & Гданьск & 77227 & $+4,8$ \\
\hline Топ-15 & & & 34343 & $+4,1$ \\
\hline Топ-3 & & &
\end{tabular}

Джерело: [10]

98 
DEVELOPMENT OF MANAGEMENT AND ENTREPRENEURSHIP METHODS ON TRANSPORT, № 4 (69), 2019
РОЗВИТОК МЕТОДІВ

УПРАВЛІННЯ ТА ГОСПОДАРЮВАННЯ

НА ТРАНСПОРТІ, № 4 (69), 2019

Переробка контейнерів в портах Чорноморсько-Азовського басейну

Табличя 3

(Болгарії, Грузіі, Молдови, Росії, Румунї, Туреччини, України) в 2008-2018 рр. (без трансиипменту)

\begin{tabular}{|c|l|c|c|c|}
\hline \multirow{2}{*}{ Номер } & \multirow{2}{*}{ Країна } & \multicolumn{2}{|c|}{ Контейнерооборот, тис. ТЕU } & \multirow{2}{*}{ Приріст, \% } \\
\cline { 3 - 4 } & & 2017 рік & 2018 рік & \\
\hline 1 & Україна & 723,7 & 847,1 & 17,0 \\
\hline 2 & Росія & 748,8 & 766,1 & 2,3 \\
\hline 3 & Румунія & 672,2 & 638,1 & $-5,1$ \\
\hline 4 & Грузія & 394,8 & 453,9 & 15,0 \\
\hline 5 & Болгарія & 225,5 & 238,3 & 5,7 \\
\hline 6 & Туреччина & 80,0 & 79,3 & 2,5 \\
\hline 7 & Молдова & 8,3 & 9,0 & 8,6 \\
\hline 8 & Крим (UА, окупація RU) & 6,5 & 5,2 & $-20,2$ \\
\hline Всього & 2859,8 & 3037,0 & 6,3 \\
\hline
\end{tabular}

Джерело: [9]

Таблиия 4

Перевантаження контейнерів

в морських торговельних портах Украӥни, тис. TEU

\begin{tabular}{|l|c|c|c|}
\hline \multirow{2}{*}{ Показник } & \multicolumn{2}{|c|}{ Контейнерооброт } & \multirow{2}{*}{ Приріст, \% } \\
\cline { 2 - 3 } & 2017 рік & 2018 рік & \\
\hline Всього: & 590267 & 846485 & 143,4 \\
\hline- експорт & 251378 & 400829 & 159,5 \\
\hline- імпорт & 303258 & 412919 & 136,2 \\
\hline- транзит & 33325 & 32657 & 98,0 \\
\hline- внутрішне сполучення & 2306 & 80 & 3,5 \\
\hline
\end{tabular}

Джерело: [3]

Аналіз внутрішніх факторів був виконаний за допомогою визначення інтегрального показника конкурентоспроможності економічного потенціалу оператора контейнерного терміналу в наступній послідовності.

Етап 1. Визначення оціночних показників. За кожною складовою були розраховані показники:

1) фінансова складова: рентабельність виробництва, коефіцієнт фінансової незалежності;
2) трудова складова: продуктивність праці, середня заробітна плата;

3) виробнича складова: пропускна спроможність причалів (TEU), співвідношення контейнерообороту i довжини причалів, рівень використання термінальних площ, продуктивність перевантажувального устаткування;

4) ринкова складова: інтенсивність обробки суден, рівень схоронності вантажів, рівень стабільності 
якості послуг (показник дотримання заявленого строку обробки та показник відносного часу очікування постановки до причалу).

Етап 2. Формування матриці оціночних показників: виділення найкращих значень по кожному показнику і привласнення їм відповідного балу.

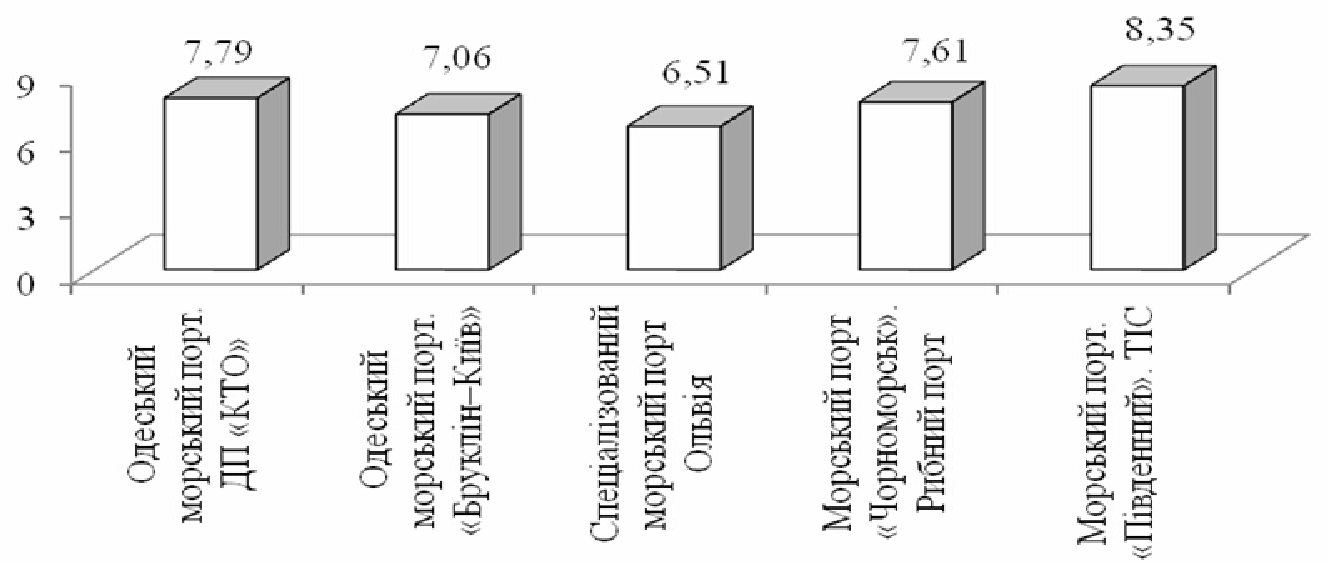

Рис. 2. Інтегральний показник конкурентоспроможності економічного потенціалу операторів контейнерних терміналів у морських портах України

Джерело: розраховано авторами з використанням [3; 9;10;13; 14]

Розрахунки були виконані на базі інформації, яка $є$ у відкритому доступі. В розрахунках не приймалися до уваги проекти розвитку, які заплановані до реалізації, або вже реалізовуються.

Висновки. В результаті дослідження були запропоновані методичні підходи, які дозволяють оцінити перспективи розвитку портових операторів. Вони містять наступні блоки: аналіз зовнішніх факторів; аналіз конкурентного середовища; аналіз внутрішніх факторів; вибір ва- ріанту розвитку; вибір об'єкту інвестування; вибір проекту 3 низки альтернативних варіантів. Отримані результати розрахунків свідчать про те, що наведені методичні підходи працюють, можуть бути використані на практиці і бути більш точними за умови використання більш повної інформації. Інтегральний показник конкурентоспроможності економічного потенціалу може бути визначений для різних інвестиційних проектів для вибору найкращого 3 них. 


\section{СПИСОК ЛІТЕРАТУРИ}

1. Аболенцева Н.О. Методы оцуенки и повышения онкурентоспособности операторов морских контейнерных терминалов: Автореферат дис.... кандидата экономических наук: 08.00.05; [C.-Петерб. гос. инженер.эконом. $\quad y H-m] .2008 .19 \quad$ c. URL: http:/leconomy-lib.com/metody-otsenki-ipovysheniya-konkurentosposobnosti-operatorov-morskih-konteynernyh-terminalov

2. Борзенкова К.С. Оченка экономического потенциала предприятия и повышение эффективности его использования: автореф. дис... канд. экон. наук. Белгород, 2003. $24 \mathrm{c}$.

3. Загальні обсяги переробки вантажів стивідорними компаніями в морських nортах за січень-грудень 2018 року (факт). URL: http://uspa.gov.ua/pokaznikiroboti

4. Краснокутська Н.С. Потенцііал підприємства: формування та оцінювання: Навчальний посібник. К.: Центр навчальної літератури, 2005. 352 с

5. Меркт Е.В. Факторы повышения конкурентоспособности порта / Розвиток методів управління та господарювання на транспорті: зб. наукових праць. Bun. 8. Одеса: ОДМУ, 2001. С. 74-85.

6. Окорокова Л.Г. Ресурсный потенцииал предприятий. СПб.: С-ПбГТУ, 2001. $293 c$.

7. Про морські порти Украӥни : Закон України від 17.05.2012 p. № 4709-VI URL: http: //zakon2.rada.gov.ua/ laws/show/4709-17.

8. Ресурсный потенциал экономического роста. Под ред. М.А. Комаров, А.Н. Романов. М.: Путь России, 2002. 567 c.

9. Чорноморський контейнерний саміт-2019: показники регіону йдуть вгору. URL: https://www.ameu.org.ua/news/4341-chornomorskij-kontejnernij-samit-2019pokazniki-regionu-jdut-vgoru

10. Шевченко Марк Контейнерні порти Свропи показують стабільне зростання. URL:https://ports.com.ua/uk/articles/konteynernye-porty-evropy-pokazyvayut-stabilnyy-rost

11. Щербина В.В., Павельчук В.О. Напрями підвищення конкурентоспроможності операторів контейнерних терміналів // Розвиток методів управління та господарювання на транспорті: зб. наукових прац̧ь. Вип. 3(68). Одеса: ОНМУ, 2019. C. 108-123. DOI 10.31375/2226-1915-2019-3-108-123

12. Kotowska, I., Mańkowska, M. \& Pluciński, M. The Competitiveness of Inland Shipping in Serving the Hinterland of the Seaports: A Case Study of the Oder Waterway and the Szczecin-Świnoujście Port Complex. In: Sierpiński, G. (ed.) Integration as Solution for Advanced Smart Urban Transport Systems. Advances in Intelligent Systems and Computing. Springer Publishing, 2018. pp. 252-263.

13. Kurudzhi Yu., Moskvichenko I, Postan M. Method of finding equilibrium solutions for duopoly of supply chains taking into account the innovative activity of enterprises/ Yu. Kurudzhi, // Eastern-European Journal of Enterprise Technologies. 2017.\#3/4 (87). P. 25-30. DOI:10.15587/1729-4061.2017.103989

14. TOP 50 WORLD CONTAINER PORTS URL: http://www.worldshipping.org/aboutthe-industry/global-trade/top-50-world-container-ports 


\section{REFERENCES}

1. Abolentseva, N.O. (2008). Metody otsenki $i$ povysheniya konkurentosposobnosti operatorov morskikh konteynernykh terminalov [Methods for assessing and improving the competitiveness of operators of sea container terminals]: avtoreferat dis.... kandidata ekonomicheskikh nauk: 08.00.05. 19. URL: http://economylib.com/metody-otsenki-i-povysheniya-konkurentosposobnosti-operatorov-morskihkonteynernyh-terminalov [in Russian].

2. Borzenkova, K.S. (2003) Otsenka ekonomicheskogo potentsiala predpriyatiya $i$ povyshenie effektivnosti ego ispolzovaniya [Assessment of the economic potential of the enterprise and increase the efficiency of its use]: avtoref. dis... kand. ekon. nauk. Belgorod [in Russian].

3. Zagalni obsyagi pererobki vantazhiv stividornimi kompaniyami v morskikh portakh za sichen- gruden 2018 roku (fakt) [2. Total volumes of cargo handling by stevedoring companies in seaports for January - December 2018 (fact)] URL: http://uspa.gov.ua/pokazniki-roboti [in Ukrainian].

4. Krasnokutska, N.S. (2005). Potentsial pidpriemstva: formuvannya ta otsi-nyuvannya [Enterprise potential: formation and evaluation]: Navchalniy posibnik. K.: Tsentr navchalnoï literaturi, 352 p. [in Ukrainian].

5. Merkt Ye.V. (2001) Faktory povysheniya konkurentosposobnosti porta [Port competitiveness factors]. Rozvitok metodiv upravlinnya ta gospodaryuvannya na transporti - Development of management and entrepreneurship methods on transport. 74-85. [in Russian].

6. Okorokovam L.G. (2001) Resursnyy potentsial predpriyatiy [Resource potential of enterprises]. SPb.: S-PbGTU. 293 p. [in Russian].

7. Pro morski porti Ukraïni [About sea ports of Ukraine]: Zakon Ukraïni vid 17.05.2012 r. № 4709-VI. URL: http: //zakon2.rada.gov.ua/ laws/ show/4709-17 [in Ukrainian].

8. Resursnyy potentsial ekonomicheskogo rosta ( 2002). [Resource potential for economic growth]. Pod red. M.A. Komarov, A.N. Romanov. M.: Put Rossii. 567 p. [in Russian].

9. «Chornomorskiy konteynerniy samit - 2019»: pokazniki regionu ydut vgoru [Black Sea Container Summit - 2019: regional indicators are coming]. URL: https://www.ameu.org.ua/news/4341-chornomorskij-kontej-nernij-samit-2019pokazniki-regionu-jdut-vgoru. [in Ukrainian].

10. Shevchenko, Mark (2019). Konteynerni porti Evropi pokazuyut stabilne zrostannya [Container ports in Europe are showing steady growth]. URL: https: // ports. com. ua/uk/articles/konteynernye-porty-evropy-pokazyvayut-stabilnyy-rost [in Ukrainian].

11. Shcherbinam, V.V. \& Pavelchukm, V.O. (2019). Napryami pidvishchennya konkurentospromozhnosti operatoriv konteynernikh terminaliv [Areas of increasing the competitiveness of container terminal operators] / Rozvitok metodiv upravlinnya ta gospodaryuvannya na transporti - Development of management and entrepreneurship methods on transport. P. 108-123 DOI 10.31375/2226-1915-2019-3108-123 [in Ukrainian].

12. Kotowska, I., Mańkowska, M. \& Pluciński, M. (2018). The Competitiveness of Inland Shipping in Serving the Hinterland of the Seaports: A Case Study of the Oder Waterway and the Szczecin-Świnoujście Port Complex. In: Sierpiński, G. (ed.) Integration as Solution for Advanced Smart Urban Transport Systems. Advances in Intelligent Systems and Computing. Springer Publishing, pp. 252-263 [in English]. 
13. Kurudzhi, Yu., Moskvichenko, I. \& Postan, M. (2017). Method of finding equilibrium solutions for duopoly of supply chains taking into account the innovative activity of enterprises. Eastern-European Journal of Enterprise Technologies. \#3/4 (87). P. 25-30. DOI:10.15587/1729-4061.2017.103989 [in English].

14. TOP 50 WORLD CONTAINER PORTS. Retrieved from http://www. worldshipping. org/about-the-industry/global-trade/top-50-world-container-ports [in English].

Стаття надійшла 22.11.2019

Посилання на статтю: Гребенник Н.Г., Старіков В.В. Методичні підходи до оцінки конкурентоспроможності економічного потенціалу портового оператору // Розвиток методів управління та господарювання на транспорті: Зб. наук. праць, 2019. № 4 (69). C. 92-103. DOI 10.31375/2226-1915-2019-4-92-103.

Article received 22.11.2019

Reference a JournalArtic: Grebennyk, N. \& Starikov V. (2019). Methodical approaches to evaluating the competitiveness of the port operator's economic potential. Development of management and entrepreneurship methods on transport, 4, 92-103. DOI 10.31375/2226-19152019-4-92-103. 